\title{
Roger Casement's Queer Archive
}

\author{
DAVID SQUIRES
}

DAVID SQUIRES is assistant professor of English at the University of Louisiana, Lafayette. With Tim Dean and Steven Ruszczycky, he edited Porn Archives (Duke UP, 2014). His current project shows how early information sciences developed as a critical discipline for negotiating neoimperial rule in the age of mass media.

596
UEER ACCOUNTS OF THE ARCHIVE HAVE NOT THEORIZED THE principle of provenance. According to archivists, provenance gives a fundamental measure of integrity to an archival collection by determining its origin and proper order. The archival turn in cultural criticism, however, has tended away from archivists' problems, drawing inspiration instead from crucial-but insufficient-insights such as Michel Foucault's formulation of the archive as "the law of what can be said" (129) and Jacques Derrida's declaration "There is no political power without control of the archive" (4). Queer criticism has successfully taken some of that control by expanding the horizon of legitimate knowledge to marginalized subjects of study. Ann Cvetkovich and Judith Halberstam, for example, have proved influential in their efforts to document archives of feeling that, in Cvetkovich's words, "serve as the foundation for public cultures" (11). Shifting the focus of queer studies from identities to publics allows both critics to imagine sexual subjectivity as messier than neat identity categories imply. Yet neither contends with the reliance of archival practice on the evidentiary value of documents, which theories of provenance explain as an effect of authorial identity. How can an archive work against the constraints of identity if its organizing logic fixes and assesses authorial subjects in normative institutional roles? This essay begins to answer that question by theorizing provenance as a narrative technique mediating the imaginative leap from historical record to historical truth. The complicated provenance of Roger Casement's archive shows how, for better or worse, imperial rule wed sexual and imperial fantasy with documentary practice, situating state records at the generic border that separates historical fact from fiction.

One hundred years after Casement's death, his archival records remain more controversial than those of perhaps any other twentieth-

(C) 2017 DAVID SQUIRES

PMLA 132.3 (2017), published by the Modern Language Association of America 
century British consul. Casement occupied the international spotlight first as a Foreign Office agent serving in Africa. In 1904 the government published his investigative reports on atrocities perpetrated against the indigenous people forced to harvest rubber in King Leopold II's Congo Free State, earning him public acclaim and state honorifics. On the heels of that success the Foreign Office sent him up the Amazon River to conduct similar investigations into the treatment of rubber harvesters in the Putumayo, a large area of the Amazon Basin. He was knighted in 1911 for his outstanding service, and, a year later, when the archival records finally entered the public sphere, the ensuing political scandal threatened to implicate British business interests, while news reports described Casement as a hero-knight. The Daily News dubbed him "Bayard of the Consular Service" (Inglis 201).

Four years later, the crown hanged him as a traitor for his involvement in Ireland's Easter Rising. British authorities cemented his legacy as a polarizing figure when they circulated copies of Casement's so-called Black Diaries, which became notorious for documenting numerous homosexual encounters. The smear stifled transatlantic publicity campaigns agitating for a reprieve from his death sentence. No doubt the sensational aspects of his life and death capture the public imagination. More to the point, however, the strategic deployment of his private papers exemplifies the political utility of maintaining archival records as tools for shaping public discourse.

The scandal surrounding Casement's sexuality changed the direction and tone of popular debates about his legacy, eventually splitting opinion on the authenticity of the Black Diaries. The prominent historians Roger Sawyer (Roger Casement's Diaries and Casement) and Angus Mitchell continue to disagree about whether they were forged. Yet those debates avoid the prosaicness of the Black Diaries, which Robert Caserio acknowledges in his seminal queer reading when he characterizes them as "a palimpsest, the data of ordinary life written over by a catalog of homosexual promiscuity" (141). The description of Casement's diaries as a palimpsest mischaracterizes their materiality as documents yet captures something crucial about how they have been read. The diaries became a palimpsest in their reception because the scandalous details of homosexual promiscuity obscured the banality of daily life. I elaborate Caserio's foundational queer reading of Casement by considering the character of data that his South American writings produced. Not simply a catalog of facts, the data arrived even to their earliest readers "shrink-wrapped," as Antoinette Burton put it in a different context, "with very little trace of how they were compiled, massaged, and otherwise packaged for mass consumption" (5-6). The data in this case were already overlaid and invested with narrative meaning.

Caserio laid the groundwork for queer readings of the Black Diaries that neither disavow Casement's sexuality nor consider it the character stain marking a "flawed hero" (Sawyer, Casement). The best studies since Caserio's have treated Casement's personal records as evidence of lost social history. Both Lucy McDiarmid and Patrick Mullen, for instance, accept the authenticity of the diaries as a matter of fact and focus instead on understanding what the diaries and the controversy surrounding them can tell us about the shifting contexts of Casement's public life. ${ }^{1}$ Through the diaries Casement becomes a major figure for postcolonial studies, allowing scholars such as Ronald Hyam to draw connections between colonial rule and the sexual ideology of British imperialism. Casement's attraction to men need not appear to contradict his humanitarian work once we recognize the signal importance of same-sex desire to understanding modernist literature and colonialism at the turn of the twentieth century. Far from contradicting Casement's diaries, the colonial record, Hyam tells us, 
has "a built-in tilt towards same-sex activity, because the empire was often an ideal arena for the practice of sexual variation" (5-6). The diaries may not reveal state forgery, but they did provoke a truth regime that made sexual intimacy a matter of state control.

I interrogate that truth regime by returning to questions of provenance and archival fidelity that the turn from forgery conspiracies left behind, even as I insist on the social value of Casement's queer sexual practices. Rather than deny Casement's sexuality, as Angus Mitchell does, I question a historical recovery of gay subjectivity that relies on what Anjali Arondekar calls "the very idiom of the archive," an idiom, I will show, that presumes too immediate an identification of historical subjects with archival objects. Understanding the archive, Arondekar explains, "mandates a theory of reading that moves away not from the nature of the object, but from the notion of an object that would somehow lead to a formulation of subjectivity: the presumption that if a body is found, then a subject can be recovered" (3). Following Arondekar, I read the principle of provenance as one nucleus of a professional idiom that enables archival collections to render subjectivity legible. Elaborating the provenance of Casement's South American writings illustrates how archives frame subjects in the public sphere by providing strategic access to information. His case presents an opportunity to rethink provenance-as a narrative structure rather than an authorial stamp-by complicating formations of archival subjectivity and, thereby, making visible the normative social fictions propping up colonial rule.

Most critics interested in Casement's sexuality turn to his personal diaries. I begin with his official South American writings because they show how archival authority works in normative ways according to what Ann Laura Stoler calls the "epistemic habits" of colonial administration (4). As a habit of archival practice, rather than a principle of archival theory, provenance can unsettle generic distinctions partitioning fact from fiction. Consider one example from Roger Casement's 1912 report on rubber production in the Putumayo:

An individual who had often taken part in these floggings and who charged himself with two murders of Indians has thus left on record the manner of flogging the Indians at stations where he served. I quote this testimony, as this man's evidence, which was in my possession when I visited the region, was amply confirmed by one of the British subjects I examined, who had himself been charged in that evidence with flogging an Indian girl whom the man in question had then shot, when her back after that flogging had putrefied, so that it became "full of maggots."

The passage is notable for several reasons, most immediately for the grotesque violence that it figures as the defining feature of the Putumayo. Closer inspection also reveals the method of discourse that produced Casement's official writings. The tangled prose correlates to the circuitous route that led Casement to most of the terror-stricken tales of flogging, torture, and murder that he sent back to London. Secondhand information, indirect witnesses, supplementary documents, and quotation all make up the archive of evidence that Casement had to cross-reference to establish the veracity of atrocities committed in the remote jungle. Casement's collection of evidence included mostly ephemeral information that he then had to form into a credible narrative. To call this archive queer is, in one sense, to indicate its strangeness. His reports make visible how institutionalized norms of archival practice lend themselves to narrative presentations of evidence. ${ }^{2}$

\section{Archival Circulation}

The story of Casement's South American investigation began in February 1908, when 
Casement traveled to Pará, Brazil, to take charge of his first Foreign Office consulate. Already well known for his campaign against King Leopold II's rubber regime in the Congo, he rode the boat to Brazil with the Peruvian rubber baron Julio César Arana, head of the Peruvian Amazon Company, which controlled the Putumayo. Eighteen months later, Casement would investigate allegations against Arana's company relating to many of the same crimes that he uncovered in the Congo. Floggings, torture, coerced labor, rape, and wanton killings resulted in the near annihilation of native populations, amounting to what we might in retrospect recognize as genocide. By 1912 those crimes would be a matter of public record. But in 1908, according to Jordan Goodman's recent biography, Casement and Arana exchanged pleasantries at the captain's table as they crossed the Atlantic (88). Arriving at his new post in Brazil with no knowledge of conditions in the Putumayo rubber forests, Casement worried more about his own working conditions than about those of the indigenous people.

Only two weeks after taking over the consulate in Pará, Casement sent a letter to the Foreign Office to complain about the state of the confidential archives, which had "not been properly kept for many years." Casement explained that he could not fulfill a particular request for information. "No copies of the circular referred to can be found in the office of this Consulate," he wrote, "although it is possible they are in existence in the archives which are stored in several chests, now lying in a cellar, and not available for present reference" (Letter). He goes on to detail the disordered and incomplete arrangement of the office's correspondence. Although banal compared to the investigative reports on violence in the Putumayo, the letter usefully illustrates a key point about modern bureaucratic archives that often goes unrecognized. They circulate.

In earlier eras, state archives centralized and preserved records for their safekeeping.
By the twentieth century, however, archival preservation did not necessarily require isolation, easing the opposition between record security and usage. Mechanical reproduction afforded more opportunities for sharing records and dramatically increased the rate of their accumulation. The major problem of administering archival collections changed from keeping them safely sequestered to providing strategic access to them. Casement's gripe about inaccessible office archives prefigures a critical point made by the influential archivist and historian Ernst Posner. In an essay about techniques for preserving local records, such as those in Pará, Posner explains that centralization "would be ideal indeed if archives needed only to be preserved and never to be used" (109). Here Posner describes the obstacle of sequestration that Casement's first letter from South America indexes. The brief letter to the Foreign Office testifies to the historical shift from storing to circulating archival collections by emphasizing the routine administrative need for accessing archived papers.

Characterizations of the archive as a repository for dead letters still outnumber those that recognize it as an engine for circulating information. At least implicitly, however, professional archivists marked the shift in administrative functions by placing public interest increasingly at the heart of archival management over the course of the twentieth century. Posner always measures the success of an archive by its annual number of inquiries and visits. ${ }^{3}$ Aside from noting professional adaptations, fully accounting for the archive as a tool that circulates information will involve thinking differently about the smartest theories of the public sphere to emerge in recent academic debates. Michael Warner, for instance, distinguishes between the archive and the public sphere by noting temporal differences in publication cycles. "In modernity," he writes, "politics takes much of its character from the temporality of the headline, not the archive." Taking seriously 
Warner's related axiom that "all publics are intertextual," however, we can begin to see how archival collections belong to the same citational field that provides more rapidly circulating texts with a basis for representation (97). The day after the Putumayo report came out in London, The New York Times published a story whose headline began RUBBER ATROCITIES SPARED No VICTIM and ended with a sensational guarantee: SIR ROGER CASEMENT'S FULL REPORT A SHOCKING PRESENTATION OF CRUELTIES PRACTICED ON NATIVES. This headline marks the publication of a state-controlled archival collection, while the archival collection it announces substantiates the credibility of information circulated by the article. A mutual interest in publicity allows government agencies to participate in politics because the strategic circulation of their archives shapes the public sphere that holds them accountable.

When the Foreign Office made Roger Casement's report on the Putumayo rubber industry public on 13 July 1912, it did so by publishing the archival collection to which his writing belonged. The form of the report's publication often goes unnoticed because subsequent, unofficial versions excerpted Casement's writing and presented it as a stand-alone document. ${ }^{4}$ Even to speak of it as a report is misleading. Casement filed five separate reports over the course of thirteen months based on two trips to the Putumayo. The official title of the archival collection that contains Casement's reports indicates the content of the archives and the context of Casement's writing: Correspondence respecting the Treatment of British Colonial Subjects and Native Indians Employed in the Collection of Rubber in the Putumayo District. Commonly referred to as the Blue Book, it places the Putumayo reports in a series of bureaucratic exchanges-by Casement and othersrelated to a transnational initiative to punish crimes associated with rubber production in the region. Taken as a whole, the publication evidences not only the intrepid humanitarian efforts that made Casement famous but also the negotiations leading up to the Foreign Office's decision to publicize those efforts.

Liberal theories of the public sphere might regard the Blue Book as a concession to public interest in governmental transparency. In a key essay on the status of contemporary public spheres, Nancy Fraser summarizes the idea of public interest: "This idea acquired force and reality in early modern Europe in the constitution of 'bourgeois public spheres' as counterweights to absolutist states. These publics aimed to mediate between 'society' and the state by holding the state accountable to 'society' via 'publicity"' (4). Testing the classic account of a public sphere against a publication like the Blue Book, however, reveals the unrealistic rigidity of a schematic opposition between publics and the vested interests of state and market forces. The Foreign Office correspondence shows that publishing the Blue Book had less to do with submitting to the scrutiny of public opinion than with drumming up public outrage over rubber-industry violence, which, the Foreign Office assumed, would engender further economic and political repercussions. The paths of influence running between state, private, and public interests formed a far-more-circular network than the counterweight metaphor suggests.

\section{Organic Records}

Despite divulging the Foreign Office's political motivations for its own publication, the Blue Book nonetheless represented an authoritative account of rubber atrocities that provided a credible basis for further representations. ${ }^{5}$ To fully grasp the nature of official credibility that gave the Blue Book its currency we must understand the archival concept of provenance. Provenance has two related meanings for archivists. First, it generally indicates the origin of a record. Who produced a record and where, when, and, in some cases, why it 
was produced all constitute provenance. Archivists share that sense of provenance with other professional collectors, including art curators, book historians, and sommeliers, with the difference that archivists attend to records rather than bottles of wine. The more specifically archival sense of provenance relates to record arrangement, which became a standard practice of organizing archival collections with the publication of Manual for the Arrangement and Description of Archives at the end of the nineteenth century (Muller et al.). Archives that follow the principle of provenance organize items not according to subject, as libraries do, but according to the order in which they accumulated during the course of institutional activity.

The principle of provenance defined in the manual precludes archivists from doing the work of selection that we attribute to curators. Instead, the archival collection refers to a group of records generated by administrative activity, accumulated for administrative purposes. As the American archivist T. R. Schellenberg put it in his landmark monograph The Management of Archives, "The principle of provenance means that records should be arranged so as to show their source in an organic body or an organic activity" (90). The Foreign Office enacted the principle of provenance when it published the Putumayo Blue Book, which begins with Casement's letter of assignment (21 July 1910) and ends with a letter from the foreign secretary stating his decision to publish the correspondence (27 June 1912). What has come to be known as the Casement report derives from his letters to the Foreign Office, which are arranged along with the other official correspondence in chronological order. Provenance offered a useful structure for the correspondence because it promised to represent the Foreign Office's operations transparently, as if to publicize the organic whole of its work to end injustices in the Putumayo, and because it made a claim to uncorrupted credibility.
Earlier accounts of the Putumayo rubberindustry atrocities told the story of villains and their victims, all of whom were vulnerable to suspicions of corruption. The American engineer Walter Hardenburg, for instance, provided an eyewitness account of atrocities to the popular British magazine Truth, framing his tale as an exposé of the Peruvian Amazon Company. Because he perceived himself as a victim of the company's misconduct, the board of directors retaliated with counteraccusations of ulterior motives for the exposé. Half a world away, the writers at Truth could do no more than call for an independent investigation. The Foreign Office's Blue Book told the story of that investigation, organizing an epistolary narrative of international diplomacy that promoted state agents to the level of protagonists. The Foreign Office's credibility derives from the institutional legitimacy of a bureaucratic office and its presumed objectivity, but the foreign secretary also picked an identifiable hero for its story. Casement's reputation after the Congo rubber scandal certified both the archival and the moral integrity of the investigation.

Theories of archival provenance avoid the journalistic and colloquial language of individual reputation. Yet individual reputation legitimates the practice of origin-based record arrangement because such an arrangement identifies the individual who created a record with the document itself, grounding archival integrity in authorial identity. The association between the person and the piece of paper establishes the document's ostensible origin. It also determines whether the document is public, private, or corporate; how it will be grouped; and its place in a group. Early formulations of the principle of provenance reified the source of information as individual persons instead of recognizing the way discursive conventions produce information. Archivists theorized provenance as the hinge between individual agency and state knowledge as if the articulation formed 
an unmediated link. That aspect of the theory of provenance allowed the Foreign Office to draw a straight line between Casement and Whitehall, portraying Casement as a technician picking facts out of the tropical flora and telegraphing them back to London. With only Casement's preliminary report in hand, Foreign Office Secretary Edward Grey felt emboldened to declare to his ambassador in Peru that "abundant and irrefutable evidence" proved many Peruvian Amazon Company officials were "unquestionably guilty of the most revolting atrocities" (Correspondence 5).

Despite the abundant evidence the Blue Book presented, its composition was both mediated and selective. As Brian Inglis explains in his biography of Casement, the Foreign Office protected British directors of the Peruvian Amazon Company by omitting correspondence that implicated them in a coverup of the atrocities (202). The Blue Book correspondence also mentions several documents that fall outside the archive because of their designation as private. A letter from the British consul in Lima to the foreign secretary in London describes a memorandum addressed to the president of Peru detailing abuses in the Putumayo. According to the letter, it "was arranged" for the memorandum to be considered "a private and unofficial communication," so it would not appear in the official record (146). Here the first sense of provenance (record origin) disqualifies the second sense (original order): the memo's origin as a private communiqué removes it from the archival order, obscuring the content of correspondence between government agencies. The result is a filing system that actively selects the archival collection instead of relying on its organic accumulation.

Correspondence in the Blue Book similarly refers to several private letters from Casement that, while part of the investigation, get excluded from the official publication. Casement played several official and unofficial roles in publicizing atrocities in the Putu- mayo, complicating his authorial identity so that no single publication could represent all his activities during the investigation. In addition to composing official correspondence, Casement corresponded with members of the Putumayo Mission Fund to raise money to establish religious oversight in the region. $\mathrm{He}$ wrote a typically patronizing article for The Contemporary Review that described the $\mathrm{Pu}$ tumayo natives as "lost children of the forest" (qtd. in Inglis 206). He even brought two Huitoto boys to London as part of the unofficial publicity campaign to raise awareness of conditions in the Putumayo, having their portrait painted and studio photographs made of them. Lesley Wylie has argued compellingly that Casement's publicity campaign evidences his complicity with British imperial ideology ("Rare Models"). Much of what Casement wrote about Putumayo natives, publicly and privately, converges with the dominant imperial imagination. Yet Wylie's sense of Casement's humanitarianism as reducible to the racist precepts of imperial power fails to consider the instability of his public identity as he moved between official and unofficial positions. Nor does Wylie consider the heterogeneity of the public sphere that constitutes the field of Casement's public addresses, not to mention how that field changed after his private notes became public. ${ }^{6}$

Casement seemed never to forget the heterogeneity of his potential audiences, as evidenced by the multiple versions of letters and journal entries that he drafted for different purposes. The full range of his activities as an anti-imperialist agitator, amateur ethnographer, and editorialist exceeded his position as a state consul. Yet, by contributing to his public reputation, those activities made it possible for the Foreign Office to organize the Blue Book around the authority of his name. The inconsistency between Casement's diverse activities and the state archive's claim to completeness points toward limitations structuring a theory of provenance that rests 
on individual identity. Cultural context determines the origin of a record as much as the identity of its creator does, and, if we understand identities themselves as culturally determined, cultural context may emerge as the greater determining factor. ${ }^{7}$

\section{Imperial Fictions}

Debates about Casement have invested heavily in negotiating his identity-in terms of sexual, religious, and political orientationpartly because they assess his writing in the cultural context of literary production, a field uniquely preoccupied by the claims and limits of authorship. For instance, while her interpretation of Casement as reducible to imperialist ideologies largely ignores the circumstances of publication that made his South American writings available, Wylie goes to great pains to place their rhetoric in the world of fiction. Describing his diaries and official reports as resting "on the borders of autobiography, confession, journalism, and fiction," Wylie explains that "such liminality-the coalescence of fact and fiction-is a persistent feature of writing on and from this border zone, where real-life events are often overlaid with Dantean or Conradian motifs" (Colombia's Forgotten Frontier 100). The concept of liminality requires an understanding of fact and fiction as profoundly, even ontologically, distinct. When Casement fails to remain on the side of factuality, Wylie suggests that he cedes the authority of fully realized humanitarianism by succumbing to the rhetoric of empire (104-20). Understanding that Casement's humanitarian project positioned him as an agent of publicity, I make the complementary but less agonistic argument that the task of communicating real conditions of violence in the Putumayo necessitated the imaginative use of narrative. Mobilizing public opinion requires the construction of credible-not necessarily factual-narratives that make information meaningful. ${ }^{8}$
The Foreign Office ensured the credibility of its information by organizing the Blue Book according to the principle of provenance, representing Casement as uniquely qualified to uncover the facts of abuse and as the single origin of valid information about rubber-industry atrocities. Casement's writing, however, attests to no such concern for the authority of identity. The overwhelming fact of violence dominates his reports to the Foreign Office, crowding out the possibility for introspection, self-reflection, and even citation of other authors. In a key passage about flogging, a prevalent form of violence in the Putumayo, the report appears to document the ongoing practice even after the Peruvian Amazon Company prohibited it. Yet Casement never witnessed rubber gatherers being flogged, as he confirms in the final sentence. The entire paragraph conveys the narrative detail that Casement provides throughout his report:

From the direct testimony laid before me at the station of Matanzas on the 18th October, to which I invited this gentleman's attention, it was clear that in that district at any rate his orders had not been obeyed, for I there learned, by personal confession of one of the floggers himself, that less than six weeks before my visit, in the month of September a native chief had been flogged to death, and had died in actual confinement in the station "stocks" between his wife and one of his children. Flogging was the least of the tortures inflicted on the failing rubber-gatherer, but it was the most universal and indiscriminate. Every section visited had its "cepo" or stocks and its duly appointed floggers in ordinary. At some of the stations the principal flogger was the station cook-two such men were directly named to me, and I ate the food they prepared, while many of their victims carried my baggage from station to station, and showed often terrible scars on their limbs inflicted at the hands of these men. Indians were often flogged while actually confined to the stocks, but this would be a sort of extra 
or gratuitous beating. The general method of flogging described to me by those who had themselves administered the lash was to apply it on the bare buttocks, the back and thighs coming in for a share of the blows, while the victim, the male or female, lay or was forcibly extended on the ground, sometimes pegged out. Needless to say, I did not witness any of these executions.

(Correspondence 34)

Given Casement's care in describing the scenes of violence, readers may well wonder at the admission that he "did not witness any of these executions." Casement's humanitarian efforts required him to cede his authority as witness by relying on testimonial accounts from employees of the Peruvian Amazon Company. Those testimonial performances and secondhand accounts of violence filled his reports as evidence of crime only to the extent that he materialized them as paper records in the official archive. Because the information does not originate with Casement, we must understand his authority to inhere less in bearing witness to violence than in his method of collating information, in his ability to collect and narrativize it for the Foreign Office. Casement's predicament exemplifies Thomas Richards's judgment that Foreign Office consuls constructed archives because they could not establish civil control. "The Empire was too far away," he writes, "and the bureaucrats of Empire had to be content to shuffle papers" (3). Shuffling papers had strategic value to Casement as an archival practice of reconstructing evidence, especially before he landed in Peru.

His task in collating information had as much to do with reading about violence as it did with taking testimony from those who had witnessed it. In preparation for his investigation, Casement took assiduous notes in his copy of the unpublished manuscript Hardenburg gave to the British press to break the Putumayo story. Although Casement does not cite the manuscript, much of what he reports has a direct affinity with Harden- burg's narrative. Both writers situate the $\mathrm{Pu}$ tumayo geographically and describe its dense vegetation, and the ethnographic details they provide about the region's native tribes are strikingly similar. Where Casement notes the "attenuated extremities" of the Huitoto, for instance (Correspondence 26), Hardenburg writes that "their limbs, especially the lower, are but little developed" (152). Casement's third report repeats several of the horrific details that Hardenburg relayed in his manuscript. Descriptions of company chiefs "pouring kerosene oil on men and women and then setting fire to them; burning men at the stake; dashing the brains out of children, and again and again cutting off the arms and legs of Indians and leaving them to speedy death in this agony" first circulated in the Peruvian newspapers that Hardenburg used as source material to supplement his eyewitness account (36). Even peripheral details that nonetheless made for disconcertingly concrete images, such as lash wounds "full of maggots," found their way from Hardenburg's testimonies into Casement's report (35). ${ }^{9}$ Perhaps most significant, three years before the Foreign Office published Casement's reports Hardenburg named all six company employees that Casement singles out as "the worst Criminals on the Putumayo" (3).

Casement's use of Hardenburg's manuscript is one way that mediated information entered the Blue Book. More important, the fact that Casement did not cite the source of this information speaks to the impersonality of the violence he documents. The victims have no names, and it does not matter who provides any given example or fact. The mass scale of violence prevents the documentation of particular cases, yet the extent of violence makes the allegations of abuse impossible to refute. After narrating one generalized scene depicting how "the Indian rubber worker ... would throw himself face downwards on the ground" before the flogging, Casement captures the evidentiary spirit of the report: "This 
picture is true," he writes, although he could never prove a particular instance. Instead of empirical evidence, Casement provides a "picture" - an imaginative representation of events beyond his immediate grasp. The truth of Casement's secondhand depiction of floggings has nothing to do with any one crime and everything to do with a system of crime that he apprehended through a methodical process of narrative retelling: rubber workers described for Casement "again and again" the violence that he never witnessed (35).

Citation, normally a crucial aspect of documentation, takes a back seat to narration because Casement needed to dramatize violence rather than prove a crime. His tendency to favor narrative over forensic evidence makes some critics uneasy; it establishes too close a generic kinship with fictional accounts of colonial violence. For example, Wylie points to a tonal similarity between Casement's reports and Joseph Conrad's Heart of Darkness (Colombia's Forgotten Frontier 86). Both writers offer an impressionistic invocation of gloomy jungle scenery. They also share a formal technique of layering sources. Heart of Darkness famously enfolds its entire drama in quotation marks, framing the quoted text with brief comments from an anonymous narrator. The narrator's anonymity compounds the mediating effect of extensive quotation by relinquishing authority to a voice that escapes identification. The quotation marks in Conrad's novella reveal an unstable relation between authorship and the authority of narrative discourse, suggesting a transpersonal subject of information rather than an identifiable source of its origin. In that sense, Conrad's fiction provides a discursive blueprint for understanding the operation of Casement's more covert-but also more credible - form of citation without quotation marks. ${ }^{10}$ The Foreign Office worked hard to inspire confidence in the authority of its information on the Putumayo. By contrast, Heart of Darkness uses quotation to raise questions about the circuits of transmission carrying information about imperial violence from the places it was inflicted to the scene of its official sanction, the metropole.

Because the Blue Book portrays Casement as narrating from the Putumayo, it elides the point of mediation that Heart of Darkness foregrounds as the scene of narration. Floating a short distance from London in the mouth of the Thames, the Nellie represents not just the cruising yawl where Marlow tells his tale but one of "the frontiers of modernism and propaganda" that Mark Wollaeger identifies in Modernism, Media, and Propaganda (37). Wollaeger shows how state publicity promoted a sense of order that did not align with real colonial enterprises, much as provenance did not accurately capture transatlantic attempts to regulate those enterprises. The company accountant that Marlow meets along the Congo makes the point clear, his "starched collars and got-up shirt-fronts" an extreme contrast to the disorder of the company camp (119). The accountant's desire for orderliness and organization prefigures Casement's complaint about consular archives in Brazil. As he explains to Marlow, "[I]t is extremely difficult to guard against clerical errors in this climate" (120). The Nellie acts as a frontier between the "apple-pie order" of administrative bookkeeping and "the chaos" of the company operations because it provides a site for narrative transmission. Specifically, it facilitates the reproduction of information suppressed by company policy. Having signed "some document" requiring him to keep company secrets, Marlow uses his floating stage to form a counterpublic out of the conflict between his experience of European society and his experiences on the Congo (111; see Warner). Under these circumstances the difference separating documentable fact and narrative fiction tips truth away from the "rot let loose in print" toward a more intimate form of storytelling shared among sailors (113). In presenting Marlow's tale, Conrad's novella provides 
a queer view of colonial records that links homosocial intimacy with the disruption of narrative coherence; inversely, the Blue Book illustrates how narrative coherence enabled state agencies and state-supported companies to publicize conceptions of modern progress.

At the outset of Heart of Darkness the anonymous narrator explains the homosocial intimacy aboard the Nellie as a shared "bond of the sea," forged in one of the all-male institutions of economic imperialism (103). Samesex intimacy among colonial subjects provides a crucial aspect of the critical perspective produced by the narrative transmission of Conrad's Congo story. Marlow's sense of intimacy with Kurtz motivates him to recount the tale; it also motivates him to manipulate Kurtz's archive of documents so that the delirious call "Exterminate all the brutes!" never falls subject to what Marlow calls the "whispering of public opinion" (154-55). Marlow's attempt to protect Kurtz's identity from public opinion also protects the inward intimacy that Marlow and Kurtz shared outside the sphere of the metropole's civilizing forces. That sense of intimacy in Heart of Darkness, mythologized as "the bond of the sea," echoes Conrad's own letters and journal entries detailing his trip up the Congo in 1890. The relationship he formed there with Casement eventually became an inverse analog to that of Marlow and Kurtz; while Marlow attempted to protect Kurtz, Conrad contributed to tarnishing Casement's reputation after the Easter Rising.

Having shared a room in Matadi, Marlow and Casement became friends and colleagues in the movement to decry imperial abuses. Conrad's Congo diary opens with a note about the "great pleasure" of meeting Casement in June 1890. He describes Casement in favorable terms: "Thinks, speaks well, most intelligent and very sympathetic." In an entry from the end of that month Conrad writes, "Parted with Casement in a very friendly manner" ("Joseph Conrad's Diary" 321). About twelve years later, Conrad treated
Casement to a mythic mode of acclaim. Even before Casement's ascendancy as "Bayard of the Consular Service," Conrad famously described the Irishman as having "a touch of the Conquistador in him." He went on to explain, "I have always thought that some particle of Las Casas' soul had found refuge in his indefatigable body" (Letter). Conrad's fond recollection of Casement's body is highly suggestive in the light of Casement's sexual tastes. Having to speculate on the basis of redolent archival clues, however, indicates that even documents with unambiguous provenance leave open questions about how individuals navigated the homosocial intimacy of colonial life.

If Casement's diaries belong to a queer archive, it is not because they give rise to a queer public, as Cvetkovich's formulation of queer archives suggests. Neither the diaries nor Conrad's novella fits into a progressive project of democratizing access to nonnormative sexual culture. However, I describe Casement's archive as queer because it registers truths about empire that often appear incredible because they evade documentary modes of verification. Writing about the scandal those diaries caused when they were finally made public, Tim Dean has argued that their "recounting of numerous homosexual conquests in the colonies must have represented an intolerable exposure of imperial ideology. Casement's diaries confirm in one genre what Conrad's fiction suggests in another-not only the reality of Belgian economic exploitation in the Congo, but also less publicized forms of sexual interaction between colonial and subaltern subjects" (315-16). Dean shows how we need not abandon the idea that novels and diaries make different claims on reality to appreciate how they both illuminate general truths about colonial relations. The details, however, may elude easy documentation, as they do in Casement's investigation of those relations in the Putumayo, even as the "picture is true." 


\section{Public Privates}

The difficulties of documentation did not undermine the authority of Casement's reports on the Peruvian Amazon Company. By one historian's estimation, they had more impact than even the Congo reports (Inglis 200). The attention their publication drew in the United Kingdom and the United States motivated parliamentary hearings that eventually liquidated the Peruvian Amazon Company, granting humanitarian histories an instance of Western liberalism defending subaltern life. The government's capacity for shaping public opinion had far-less-salutary outcomes for Casement during the summer of 1916. After they captured him on lonely Banna Strand, as the ballad goes, British authorities leaked Casement's personal diaries to dampen the surge of support for the revolutionary Irishman and outrage over his treatment. Ernley Blackwell, chief legal counsel to the British Cabinet, issued a memorandum that recommended "by judicious means to use these diaries to prevent Casement attaining martyrdom." His status as a martyr continues to be debated even today, but the hope for a reprieve faded quickly as some of Casement's old allies read the journals and stopped advocating for him. Even Conrad retrofitted his opinion of Casement to align with the standard homophobia of the day: "By emotional force (Congo report, Putumayo-etc) he made his way, and sheer emotionalism has undone him. A creature of sheer temperament-a truly tragic personality: all but the greatness of which he had not a trace. Only vanity" (qtd. in Reid 15). Scotland Yard's targeted publicity campaign had its effect. Unlike his character Marlow, who protected Kurtz's reputation, Conrad helped destroy Casement's, characterizing Casement as irrational and ineffective, his homosexuality somehow transforming his humanitarianism into mere narcissism.

Subsequent debates about Casement's private diaries reflected the same assump- tions of provenance that contributed to the Blue Book's authority. The links connecting identity, authenticity, and documentation guaranteed by the principle of provenance warranted his juridical sentence in the court of public opinion. The logic of authenticity supposes that if Casement did in fact write the diaries they must manifest his sexuality, just as they provide a historical record of his daily activities. The step from reading the diaries as records of activity to reading them as records of a life takes for granted that the sexually explicit diary entries confirm Casement's identity. ${ }^{11}$ One Home Office memorandum circulated at a Cabinet meeting makes the leap from sexual practice to sexual identity explicit, referring to Casement's "grossest sodomitical practices" and claiming that "he seems to have completed the full circle of sexual degeneracy, and from a pervert has become an invert" (qtd. in Mitchell, Amazon Journal 18n2). Other memorandums suggest that authorities went to considerable lengths to fix his identity in terms of both criminalized sexual behavior and pathologized subjectivity. A postmortem probe of his anus was supposed to have documented bodily evidence of Casement's trip around "the full circle of sexual degeneracy." Twentieth-century transformations in sexual politics shed a more favorable light on Casement's queerness, yet interpretive methods that affirm his homosexuality rely on a reductive equation of his private documents and sexual identity. Appreciating how the Putumayo report relies on the careful construction of an archive to support its credibility should remind us that Casement's private notes had already undergone significant archival, editorial, and political interpretation by the time they ever reached a public readership.

Only recently, as forgery theories appear increasingly implausible, has the possibility of fantasy entered the discussion. As Mario Vargas Llosa puts it, "We do not know how much of himself he put into those diaries, 
or whether they were also a fantasy, a fiction through which he attempted to fill the emptiness of his life" (qtd. in Tóibín). The imputed despair aside, Vargas Llosa's remark casts fantasy as a psychic operation mediating the forensic and social value of Casement's journals. Given some of the details that Casement records, it is a wonder that critics have not yet regarded such a possibility as obvious. The invariably and improbably large size of his lovers' penises belies the evidentiary value of the diaries despite their authenticity. "Perfectly huge," he writes of one young man in Rio. At eight-and-a-half inches, the young man, Casement claims, is the biggest he has had since a husky lover in Lisbon six years earlier. "'Nunca veio meior!' Nunca," he added in Portuguese (Black Diaries 207). ${ }^{12}$

The subtle disconsolation registered by Casement's repetition of nunca ("never") makes sense considering how interminable the six-year period between well-hung lovers must have seemed to him. With a little distance and the benefit of empirical science, however, we can appreciate the extent of his good fortune. One recent study reports that an eight-and-a-half-inch penis sits comfortably in the upper echelons of the ninety-ninth percentile of above-average male genitalia. Statistical probability suggests that Casement would have needed to encounter well over three hundred penises in order to find two as extraordinary as the ones he met in Lisbon and Rio. ${ }^{13}$ Far from empty, it seems that his six years between encounters must have been saturated with erotic excitement. That, anyway, would be the conclusion if we took the measurements as documentary evidence of his daily activities. Further examples from the diaries suggest that details Casement recorded about his sexual partners relied more on fantastical exaggeration than sound estimation. Quite improbably, less than a month after his second eight-and-a-half-inch encounter, Casement records details about a gentleman named Ramón. "Splendid erections," he writes, "10" at least" (207). Later that same spring he mentions a lover in Belfast, describing him as "huge \& curved \& he awfully keen" (211). Even in the far reaches of the Putumayo, Casement seems to have chanced upon extraordinarily long penises: "a young Cholo with erection as he carried a heavy box," he jotted in his notes. "Down left leg about 6-8" inches" (235). Every penis he describes is so unusually large that the sexual entries of his diary read like casting notes for a film studio in San Fernando Valley: "Enormous over 7 1/2" I think"; "leant on gunwale with huge erection about 8"'; "an enormous offer-about 9"' $(211,291,307)$. In all probability these entries do not represent an empirical record of Casement's sexual encounters. They do, however, record one way that sexual fantasy and desire take shape through documentation. In that sense Casement's notes on penis size evidence an archival practice that produces pleasure without claiming to document subjects, much less subjective experience or identity.

The possibility that Casement used the diaries as a tool for sexual fantasy, as Vargas Llosa suggests, offers an intuitive theory for making sense of the outsized data that they record. It takes little effort to imagine a closeted homosexual man dreaming of the cruisy life he would like to lead in South America. Yet the image Vargas Llosa conjures as he introduces fantasy to the interpretive equation obscures sexual activity as common to Casement's daily experience in order to privilege homosexual identity as essential to Casement's subjective experience. Read through the matrix of identity, the Black Diaries fall neatly into a long history of colonial racism. Casement's obsession with extraordinary penises might remind critical readers such as Wylie of Frantz Fanon's famous line on the tradition of representation that reduces African men to the image of a fantastically large phallus. Fanon argues, "[T]he Negro is eclipsed. He is turned into a penis. He is a penis" (130). Gesturing to the popular myth 
that black men have larger penises than white and Asian men, Fanon goes on to explain, "The average length of the penis among the black men of Africa, Dr. Pales says, rarely exceeds 120 millimeters (4.6244 inches). Testut, in his Traité d'anatomie humaine, offers the same figure for the European. But these are facts that persuade no one" (130-31). The persistence of the myth, Fanon shows, protects white men from the threat of otherness by helping them maintain a self-image as not only more civilized but also more human than black and brown men. Extending Fanon's analysis to Casement would liken the consul to European explorers such as Richard Burton and Jacobus Sutor who claimed to have measured penises up to twelve inches long (Friedman 104). ${ }^{14}$ In contrast to Vargas Llosa, this lineage demonstrates how fantasy can shape the documentation of actual encounters rather than merely substitute for them.

While the Black Diaries resonate with aspects of the racist tradition that Fanon diagnoses, they avoid major pitfalls of imperial ideology by circumventing the question of racial or sexual identity. In addition to noting the size of black, brown, and white penises with equal zeal, Casement's notes about lovers never assume that their bodies indicate anything about their interiority or subjective experience. Problems of degeneration, psychology, and primitivism are entirely absent. One entry that is especially contested in the forgery debates illustrates how far the accounts of Casement's sexual activities stray from identity: "Left for Warrenpoint with Millar. Boated \& Huge Enjoyment. Both Enjoyed. He came to lunch at G Central Hotel. Turned in together at 10.30 to 11 after watching billiards. Not a word said till-'Wait-I'll untie it' \& then 'Grand' X Told many tales \& pulled it off on top grandly. First time-after so many years \& so deep mutual longing. Rode gloriously-splendid steed. Huge - told of many-'Grand"' (Black Diaries 211). Although Joseph Millar Gordon is an old friend of Casement's, what we mostly learn of him in this passage is his proficiency as a top. The vague reference to their past together only heightens the erotic intensity, while all the pleasures described, even the pleasure of storytelling, relate to their physical activity.

Privileging sexual action over subjectivity, Casement's private diaries trouble the evidentiary value that theories of provenance categorize as identity. Instead, the diaries offer us, a public they never meant to address, a representation of impersonal pleasures that consolidated his work for and against British imperialism. The principle of provenance links those documents of promiscuous imagination to Casement as a historical subject, transforming acts of writing into an authorial identity institutionalized as Irish revolutionary, traitor to the British, sexual invert, protohumanitarian hero, martyr of gay history. To recognize provenance not as principle but as practice-one method for narrating historical truth-invites instead a reading of historical acts. In that way, the archival collections associated with Casement's name make histories of mass violence and sexual intimacy legible through historically specific practices of writing that do not resolve into identity. Reading the archival record for impersonal modes of representation may well render queer practices where no queer subjects exist. To appreciate how such a reading allows the personal data of Casement's private diaries to inform our understanding of overwhelming imperial violence, we need only recognize imperial archives as discursive works of imagination rather than individual productions of fact.

\section{NOTES}

1. Mullen writes, "Despite lingering conspiracy theories that point to the ambiguous provenance of the diaries, the evidence overwhelmingly suggests that the diaries are authentic" (78). 
2. Davis and Steedman both make the similar point that archives are conducive to narrative accounts of history. I suggest, by contrast, that an archival collection itself can adopt narrative structure.

3. Posner lauds the Danish state archives for centralizing records while promoting public access: "In 1938 these repositories were visited by 13,500 searchers, who ordered well-nigh 120,000 documents" (109). He attributes their success, however, to the smallness of the country. Where great geographic distances separate archives and publics, circulation promotes usage better than centralization.

4. The influential edition from Grove Press, The Black Diaries: An Account of Roger Casement's Life and Times, edited by Peter Singleton-Gates and Maurice Girodias, is an example. Despite its shortcomings, I use this edition of Casement's diaries as a source because, by juxtaposing the Putumayo reports with the Black Diaries, it does as a matter of design what this essay attempts as a matter of interpretation.

5. The Blue Book inspired several book-length publications that used it to elaborate complementary and critical perspectives. Most famously, the Colombian author José Eustasio Rivera created a fictional narrative out of Casement's writings titled La vorágine (The Vortex).

6. Debates about the reliability of Casement's reports echo debates from the late twentieth century about the function of the Latin American genre testimonio. Arias analyzes those debates in the context of the Rigoberta Menchú controversy.

7. Recent archivists have made similar points about the principle of provenance as practiced today (Beattie; Nesmith). Beattie offers an especially useful discussion of provenance and diaries, beginning with a crucial insight: "Traditional archival description forms a very narrow basis for understanding these records because of the myriad forms diaries can take and roles they can play in their creators' lives" (82).

8. Taussig has pointed out that most of the evidence we have of rubber-industry atrocities comes to us in narrative form. He reads those narratives as "epistemic murk" (482), while I see them as offering alternative epistemologies for apprehending the otherwise unapproachable fact of mass violence.

9. The passage in Hardenburg's manuscript that corresponds to Casement's disturbing image is a translation of testimony originally given to Saldaña Roca and published in his paper La sanción: "and as the scars received no treatment in a few days maggots bred in them" (229-30).

10. Keane analyzes how quotation marks function in Casement's short pamphlet "The Language of the Outlaw."

11. Inglis's introduction to the 1993 edition of his biography of Casement offers an example of this reductive assumption. Forensic testing, Inglis argues, "would be superfluous, so strong is the evidence of Casement's homosexuality" (qtd. in Mitchell, "Phases" 94). The question of Casement's identity appears here entirely bound up with the authenticity of his diaries.
12. While Singleton-Gates and Girodias do not translate Casement's entries, Sawyer does. He has "[n]ever see again” (Roger Casement's Diaries 43). Because Casement's Portuguese is not perfect, two other possibilities exist: "never saw bigger" and "never came better."

13. My calculations rely on data from a recent study of 1,661 men in the United States who self-reported measurements of their erect penises. The numbers are consistent with those of other studies published over the past decade. These studies suggest that the vast majority of fully erect penises top out between five-and-a-half and six inches (Herbenick et al.; cf. Mondaini and Gontero; Wylie and Eardley; Khan et al.).

14. Friedman traces the racialization of penis size from the early seventeenth century to the late twentieth century. He argues that Western thought associated dark skin with large genitalia as a way to dehumanize black subjects. Sutor, for instance, compares the twelve-inch penises he supposedly found on Sudanese men to a donkey's genitals (Friedman 104). Friedman's numerous examples demonstrate how exceptional Casement was for regarding a large penis as a personal attribute rather than a racial detriment.

15. For more on the controversy see Sawyer (Roger Casement's Diaries 52-53n27) and McDiarmid (208-09). Related news stories are available online (e.g., McDonald).

\section{Works Cited}

Arias, Arturo. "Authoring Ethnicized Subjects: Rigoberta Menchú and the Performative Production of the Subaltern Self." PMLA, vol. 116, no. 1, Jan. 2001, pp. 75-88.

Arondekar, Anjali. For the Record: On Sexuality and the Colonial Archive in India. Duke UP, 2009.

Beattie, Heather. "Where Narratives Meet: Archival Description, Provenance, and Women's Diaries." Libraries and the Cultural Record, vol. 44, no. 1, 2009, pp. 82-100.

Blackwell, Ernley. “The Casement Case.” 15 July 1916 , CAB 37/151/35. The National Archives, London.

Burton, Antoinette. "Archive Fever, Archive Stories." Introduction. Archive Stories: Facts, Fictions, and the Writing of History, Duke UP, 2005, pp. 1-24.

Casement, Roger. The Black Diaries: An Account of Roger Casement's Life and Times, with a Collection of His Diaries and Public Writings. Edited by Peter SingletonGates and Maurice Girodias, Grove Press, 1959.

. Letter to Lord Dufferin. 14 Mar. 1908, National Library of Ireland, MS 13,087/1.

Caserio, Robert L. "Casement, Joyce, and Pound: Some New Meanings of Treason." Quare Joyce, edited by Joseph Valente, U of Michigan P, 1998, pp. 139-55.

Conrad, Joseph. Heart of Darkness. Heart of Darkness and Other Tales, edited by Cedric Watts, Oxford UP, 1990, pp. 101-87. 
"Joseph Conrad's Diary (Hitherto Unpublished) of His Journey up the Valley of the Congo in 1890." The Blue Peter, vol. 5, no. 43, Oct. 1925, pp. 318-25.

- Letter to R. B. Cunninghame Graham. 26 Dec. 1903. Joseph Conrad's Letters to R. B. Cunninghame, edited by C. T. Watts, Cambridge UP, 2011, letter 49, pp. 148-49.

Correspondence respecting the Treatment of British Colonial Subjects and Native Indians Employed in the Collection of Rubber in the Putumayo District. His Majesty's Stationery Office, 1912.

Cvetkovich, Ann. An Archive of Feelings: Trauma, Sexuality, and Lesbian Public Cultures. Duke UP, 2003.

Davis, Natalie Z. "On the Lame." The American Historical Review, vol. 93, no. 3, June 1988, pp. 572-603.

Dean, Tim. “The Germs of Empire." The Psychoanalysis of Race, edited by Christopher Lane, Columbia UP, 1998, pp. 305-29.

Derrida, Jacques. Archive Fever: A Freudian Impression. Translated by Eric Prenowitz, U of Chicago P, 1995.

Fanon, Frantz. Black Skin, White Masks. Translated by Charles Lam Markmann, Pluto Press, 2008.

Foucault, Michel. The Archaeology of Knowledge. Translated by A. M. Sheridan Smith, Pantheon Books, 1972.

Fraser, Nancy. "Rethinking the Public Sphere: A Contribution to the Critique of Actually Existing Democracy." The Phantom Public Sphere, edited by Bruce Robbins, U of Minnesota P, 1993, pp. 1-32. Vol. 5 of Cultural Politics.

Friedman, David M. A Mind of Its Own: A Cultural History of the Penis. Free Press, 2001.

Goodman, Jordan. The Devil and Mr. Casement. Farrar, Straus and Giroux, 2009.

Halberstam, Judith. In A Queer Time and Place: Transgender Bodies, Subcultural Lives. New York UP, 2005.

Hardenburg, W. E. The Putumayo, the Devil's Paradise; Travels in the Peruvian Amazon Region and an Account of the Atrocities Committed upon the Indians Therein. T. F. Unwin, 1912.

Herbenick, Debby, et al. "Erect Penile Length and Circumference Dimensions of 1,661 Sexually Active Men in the United States." Journal of Sexual Medicine, vol. 11, no. 1, Jan. 2014, pp. 93-101.

Hyam, Ronald. Empire and Sexuality: The British Experience. Manchester UP, 1990.

Inglis, Brian. Roger Casement. Hodder and Stoughton, 1973.

Keane, Damien. "Quotation Marks, the Gramophone Record, and the Language of the Outlaw." Texas Studies in Literature and Language, vol. 51, no. 4, Winter 2009, pp. 400-15.

Khan, Shahid, et al. "Establishing a Reference Range for Penile Length in Caucasian British Men: A Prospec- tive Study of 609 Men." BJU International, vol. 109, no. 5, Mar. 2012, pp. 740-44.

McDiarmid, Lucy. The Irish Art of Controversy. Cornell UP, 2005.

McDonald, Henry. "Outcry as Secret Gay Life of Irish Hero Is 'Proved." The Observer, 24 July 1999, www .theguardian.com/uk/1999/jul/25/henrymcdonald theobserver.

Mitchell, Angus. The Amazon Journal of Roger Casement. Anaconda Editions, 1997.

_. "'Phases of a Dishonourable Phantasy." Field Day Review, vol. 8, 2012, pp. 85-125.

Mondaini, Nicola, and Paolo Gontero. "Idiopathic Short Penis: Myth or Reality?” BJU International, vol. 95, no. 1, Jan. 2005, pp. 8-9.

Mullen, Patrick. The Poor Bugger's Tool: Irish Modernism, Queer Labor, and Postcolonial History. Oxford UP, 2012.

Muller, S., et al. Manual for the Arrangement and Description of Archives. Translated by Arthur H. Leavitt, Society of American Archivists, 1940.

Nesmith, Tom. "Seeing Archives: Postmodernism and the Changing Intellectual Place of Archives." American Archivist, vol. 65, no. 1, Spring-Summer 2002, pp. 24-41.

Posner, Ernst. "European Experiences in Protecting and Preserving Local Records." Archives and the Public Interest, Public Affairs Press, 1967, pp. 107-13.

Reid, B. L. The Lives of Roger Casement. Yale UP, 1976.

Richards, Thomas. The Imperial Archive: Knowledge and the Fantasy of Empire. Verso, 1993.

Rivera, José Eustasio. The Vortex. Translated by Earle K. James, Panamericana Editorial, 2001.

"Rubber Atrocities Spared No Victim." The New York Times, 14 July 1912, p. C3.

Sawyer, Roger. Casement: The Flawed Hero. Routledge and Kegan Paul, 1984.

- Roger Casement's Diaries: 1910: The Black and the White. Pilmco, 1997.

Schellenberg, T. R. The Management of Archives. Columbia UP, 1965.

Steedman, Carolyn. Dust: The Archive and Cultural History. Rutgers UP, 2002.

Stoler, Ann Laura. Along the Archival Grain: Epistemic Anxieties and Colonial Common Sense. Princeton UP, 2010.

Taussig, Michael. "Culture of Terror-Space of Death: Roger Casement's Putumayo Report and the Explanation of Torture." Comparative Studies in Society and History, vol. 26, no. 3, July 1984, pp. 467-97.

Tóibín, Colm. “A Man of No Mind.” London Review of Books, vol. 34, no. 17, 13 Sept. 2012, pp. 15-16.

Warner, Michael. "Publics and Counterpublics." Publics and Counterpublics, Zone Books, 2005, pp. 65-124. 
Wollaeger, Mark. Modernism, Media, and Propaganda: British Narrative from 1900 to 1945. Princeton UP, 2006.

Wylie, Kevan R., and Ian Eardley. "Penile Size and the 'Small Penis Syndrome.'” BJU International, vol. 99, no. 6, June 2007, pp. 1449-55.
Wylie, Lesley. Colombia's Forgotten Frontier: A Literary Geography of the Putumayo. Liverpool UP, 2013.

- "Rare Models: Roger Casement, the Amazon, and the Ethnographic Picturesque." Irish Studies Review, vol. 18, no. 3, Aug. 2010, pp. 315-30. 